\title{
Allergic diseases of the skin and drug allergies - 2023. Sulfamethoxazole/trimethoprim induced leukocyte count decreased in 79-year-old female patient
}

Vesna Radovic

From 2nd WAO International Scientific Conference (WISC 2012)

Hyderabad, India. 6-9 December 2012

\section{Background}

This report was received from a physician via Medicines and Medical Devices Agency of Serbia on 2012-Feb-08.

\section{Methods}

Case report

\section{Results}

A 79-old-year female patient was taking Trimosul (INN: sulfamethoxazole / trimethoprim) $400 \mathrm{mg} / 80 \mathrm{mg}$ tablets 2 tablets twice daily from 2012-Jan-05 to 2012Jan-09 for urinary tract infection. On 2012-Jan-09 her total leukocyte count decreased. The suspected drug was withdrawn and her leukocyte count gradually increased. The patient had no previous history of any drug allergy. Laboratory test showed low level of folic acid $1.5 \mathrm{ng} / \mathrm{mL}$ (ref. values $2.7-3.4 \mathrm{ng} / \mathrm{mL}$ ). Concomitant medication was Farin (INN: warfarin) $1 \mathrm{mg}$ daily for pulmonary embolism since 2012-Jan-02 and Ranisan (INN: ranitidine) $150 \mathrm{mg}$ twice daily for gastritis since 2011-Dec-27.

\section{Conclusions}

This case was classified as serious. The causal relationship between sulfamethoxazole / trimethoprim and the suspected adverese reaction was assessed as possibly related based on the temporal association and the known safety profile of the drug. The suspected adverse reactions is listed according to the current Reference

Pharmacovigilance, STADA Hemofarm A.D., Belgrade, Serbia
Safety Information (RSI). This case does not change the overall benefit-risk balance of the medicinal product.

Published: 23 April 2013

\section{doi:10.1186/1939-4551-6-S1-P110}

Cite this article as: Radovic: Allergic diseases of the skin and drug allergies - 2023. Sulfamethoxazole/trimethoprim induced leukocyte count decreased in 79-year-old female patient. World Allergy Organization Journal 2013 6(Suppl 1):P110.

Submit your next manuscript to BioMed Central and take full advantage of:

- Convenient online submission

- Thorough peer review

- No space constraints or color figure charges

- Immediate publication on acceptance

- Inclusion in PubMed, CAS, Scopus and Google Scholar

- Research which is freely available for redistribution

Submit your manuscript at www.biomedcentral.com/submit C Biomed Central 